\title{
POTENSI KARBON BERBASIS PEKARANGAN DI KAMPUNG MUBRAIDIBA KABUPATEN MANOKWARI
}

\section{(House Yard Carbon Based Potency in Mubraidiba Village of Manokwari)}

\author{
Katrin Sriyani Udimeraa ${ }^{1}$, Zulfikar Mardiyadi ${ }^{1}$ dan Dina Arung Padang ${ }^{1 凶}$ \\ Jurusan Kehutanan, Fakultas Kehutanan Universitas Papua Manokwari, Papua Barat, \\ 98314. Tlp/Fax: +62986211065. \\ $\triangle$ Penulis Korespondensi: Email: dinaap@yahoo.com \\ Diterima: 10 Mar 2017| Disetujui: 29 Mar 2017
}

\begin{abstract}
Abstrak
Identifikasi potensi biomasa dan karbon penting dalam upaya kontribusi menjaga keseimbangan lingkungan global. Tujuan dari penelitian ini adalah untuk mengetahui besaran potensi karbon pekarangan di kampung Mubraidiba. Metode yang digunakan ialah deskriptif dengan teknik observasi lapang yang dilakukan secara sensus terhadap seluruh tanaman pertanian, perkebunan dan kehutanan yang selanjutnya dibagi berdasarkan keleas diameter. Persamaan alometrik digunakan untuk menduga besaran nilai biomasa yang disesuaikan dengan karakteristik dan jenis tanaman yang ditemukan. Hasil penelitian menunjukkan bahwa jenis-jenis tanaman di pekarangan kampung Mubraidiba dilakukan pada 2 (dua) kelas diameter, yaitu kelas diameter $5-30 \mathrm{~cm}$ dan kelas diameter $30 \mathrm{~cm}$ up. Selain itu, pengelompokan tanaman juga dilakukan berdasarkan jenis tanaman kehutanan, pertanian dan perkebunan dengan jumlah jenis tanaman pertanian dan perkebunan pada kelas diameter 5 - $30 \mathrm{~cm}$ lebih banyak $(66,67 \%)$ dibanding jenis tanaman kehutanan $(33,33 \%)$. Selain itu, fungsi antara kebun campuran dan pekarangan sedikit berbeda antara kebun campuran dengan tujuan produktivitas dan pekarangan dengan fungsi produktivitas dan fungsi keindahan serta kenyamanan tinggal. Rata-rata nilai biomasa pohon untuk kelas diameter $5-30 \mathrm{~cm}$ adalah 1,9951 ton/pekarangan, sedangkan rata-rata biomasa tanaman pertanian sebesar 1,7035 ton/pekarangan. Rata-rata total nilai karbon pohon diameter 5-30 $\mathrm{cm}$ sebesar 2,6994 ton/pekarangan, sementara stok karbon pada tanaman kehutanan ratarata dengan diameter $5-30 \mathrm{~cm}$ sebesar 3,7898 ton, sedangkan stok karbon tanaman pertanian dan perkebunan rata-rata sebesar 0,8518 ton/pekarangan.
\end{abstract}

Kata kunci: Nilai karbon, kandungan biomasa, pekarangan, persamaan alometrik, kampung Mubraidiba

\begin{abstract}
Identifying the potency of biomass and carbon was fundamental in contributing to the global environmental balance. The aim of the study was to understand amount of carbon sequestered in the house yard in Mubraidiba village. Descriptive method has been used by way of field observation technique that carried out trough census towards all agriculture, plantation, and forest plant commodities that classified into the diameter classes. Allometric equation was applied to predict amount of biomass content based on the plant type equation formula. The result pointed out there were various numbers of plant types and classes found which has been classified into two diameter classes such as 5 to $30 \mathrm{~cm}$
\end{abstract}


and $>30 \mathrm{~cm}$. In addition, plants have been grouped such as for forestry, plantation, and agriculture. Agricultural based plant commodity turned out to be the most found plant $(55.67 \%)$ compared to forestry based plant $(33.33 \%)$. There was a little differentiation between combined garden and house yard. The average of biomass amount for trees with the diameter classes from 5 to $30 \mathrm{~cm}$ was 1,9951 ton/house yard, while the average biomass amount for agricultural plants was 1,7035 ton/house yard. Moreover, the average total amount of carbon for trees that ranging from 5 to $30 \mathrm{~cm}$ was 2,6994 ton/house yard, and the total average amount of carbon from forestry sector with the diameter ranging from 5 to $30 \mathrm{~cm}$ was 3,7898 ton, while the total average amount of carbon from agriculture and plantation commodities was 0,8518 ton/house yard.

Keywords: Carbon amount, biomass content, house yard, allometric equation, Mubraidiba village.

\section{PENDAHULUAN}

Perubahan iklim global pada dekade terakhir ini terjadi karena terganggunya keseimbangan energi antara bumi dan atmosfir akibat meningkatnya konsentrasi gas rumah kaca (GRK), terutama karbondioksida $\left(\mathrm{CO}_{2}\right)$. Meningkatnya konsentrasi $\mathrm{CO}_{2}$ disebabkan oleh pengelolaan lahan yang kurang tepat, antara lain pembakaran hutan dalam skala luas secara bersamaan dan pengeringan lahan gambut untuk pembukaan lahanlahan pertanian (Hairiah dan Rahayu 2007).

Upaya penurunan emisi sektor kehutanan dapat dilakukan dengan berbagai cara. Pada prinsipnya adalah pengurangan emisi dengan menjaga dan mempertahankan stok karbon yang ada serta meningkatkan serapan melalui berbagai program pembangunan hutan tanaman. Salah satu mekanisme pengurangan emisi yang sedang dikembangkan adalah mekanisme REDD+ (Reduced Emission from Deforestation and forest Degradation Plus). REDD+ adalah istilah yang mengacu pada bali action plan yaitu pendekatan kebijakan dan insentif positif pada isu-isu yang berkenaan dengan mengurangi emisi dari penurunan kerusakan hutan dan tutupan hutan (Wibowo 2012).

Hutan alami merupakan penyimpanan karbon (C) tertinggi bila dibandingkan dengan sistem penggunaan lahan pertanian. Oleh karena itu, hutan alami dengan keragaman jenis pepohonan berumur panjang dan serasah yang banyak merupakan gudang penyimpanan $\mathrm{C}$ tertinggi. Bila hutan diubah fungsinya menjadi lahan-lahan pertanian, perkebunan atau ladang penggembalaan maka jumlah $\mathrm{C}$ tersimpan akan merosot. Jumlah $\mathrm{C}$ tersimpan antar lahan tersebut berbeda-beda tergantung pada keragaman dan kerapatan tumbuhan yang ada, jenis tanahnya serta cara pengelolaannya (Hairiah dkk. 2011).

Indonesia memiliki berbagai macam bentuk pemanfaatan lahan, mulai dari yang paling ekstensif misalnya agroforestri kompleks yang menyerupai hutan, hingga paling intensif seperti sistem pertanian semusim monokultur. Pengukuran secara kuantitatif C tersimpan dalam berbagai macam penggunaan lahan perlu dilakukan. Salah satu kontribusi yang dilakukan oleh Indonesia terhadap isu global adalah melalui perannya dalam mengurangi 
emisi GRK dan meningkatkan persediaan karbon hutan melalui konservasi hutan yang mekanismenya di tingkat global sedang dibangun melalui kegiatan REDD + . Hal ini didukung oleh luasnya hutan konservasi di Indonesia yang mencapai 26,8 juta ha yang terdiri dari Taman Nasional, Cagar Alam dan Hutan Rekreasi (Wibowo 2012).

Provinsi Papua Barat memiliki hutan seluas 9.361.073 ha atau sekitar 8,12\% terhadap luas hutan Indonesia $(\mathrm{BPKH}$, 2012). Masyarakat yang bermukim di sekitar hutan pada masa lalu dan sekarang memanfaatkan hutan sebagai sumber mata pencaharian, selain itu hutan juga menjadi wilayah atau tempat perladangan berpindah. Namun seiring dengan berjalannya waktu dan dengan semakin jauhnya akses terhadap wilayah-wilayah yang memungkinkan dilakukan perladangan berpindah, maka masyarakat di masa sekarang ini lebih memilih untuk memanfaatkan pekarangan sebagai tempat untuk bercocok tanam untuk mengusahakan tanaman-tanaman baik pertanian maupun kehutanan yang dianggap dapat memberikan kontribusi terhadap perekonomian masyarakat.

Kampung Mubraidiba memiliki pekarangan yang cukup luas dengan jumlah tanaman yang cukup banyak dan beragam. Secara tidak langsung tanaman tersebut memberikan manfaat yang sangat besar yaitu sebagai penyerap karbon. Salah satu komponen karbon yang dapat dihitung di kampung ini adalah perhitungan karbon di pekarangan. Oleh karena itu, penelitian ini perlu dilakukan untuk menghitung besarnya karbon pekarangan di Kampung Mubraidiba Distrik Manokwari Utara Kabupaten Manokwari.

\section{METODE PENELITIAN}

Penelitian ini dilaksanakan di kampung Mubraidiba distrik Manokwari Utara kabupaten Manokwari selama kurang lebih 3 bulan yang terhitung dari tanggal 1 Maret sampai 31 Mei 2013. Kegiatan penelitian ini meliputi seluruh vegetasi yang terdapat di pekarangan rumah dengan menggunakan metode deskriptif dengan teknik observasi lapang yang dilakukan secara sensus terhadap seluruh tanaman pertanian, perkebunan dan kehutanan yang terdapat di dalam pekarangan yang secara tekniks meliputi: pengukuran luas pekarangan, pengamatan semua jenis tanaman yang ada di dalam pekarangan, serta pengukuran diameter tanaman $(5-30 \mathrm{~cm}$ dan $>30 \mathrm{~cm})$ dan variabel tinggi pohon.

\section{Metode dan Analisis Data}

Untuk mengetahui biomassa pada tanaman dilakukan perhitungan dengan menggunakan persamaan allometrik sebagai berikut: Jenis tanaman pisang (Musa sp.) menggunakan persamaan alometrik $\mathrm{Y}=0,0303 \quad \mathrm{D}^{2,1345}$ (Arifin 2001); untuk jenis tanaman palem (Arecacea) menggunakan persamaan alometrik $Y=\exp \{-2,134+2,530 x \ln (\mathrm{D})\}$ (Brown 1997). Sementara untuk jenis tanaman yang lain digunakan persamaan alometrik umum berdasarkan Brown (1997): $\mathrm{Y}=42,69-12,8 \mathrm{D}+1,242 \mathrm{D}^{2}$, dimana $\mathrm{Y}=$ berat biomasa (kg/pohon) dan $\mathrm{D}=$ diameter pohon $(\mathrm{cm})$. Selanjutnya guna menduga kandungan $\mathrm{C}$ di atas permukaan tanah, digunakan persamaan Brown (1997) sebagai berikut:

$$
\mathrm{Wtc}=\mathrm{Y} \times 0,5
$$

dimana Wtc : Kandungan karbon di atas permukaan tanah (ton); $\mathrm{Y}=$ nilai 
biomasa (ton); dan $0,5=$ asusmsi $50 \%$ karbon tersimpan. Selanjutnya guna mengetahui besaran serapan karbondioksida berdasarkan nilai diameter pohon perhektarnya, digunakan rumus: $\mathrm{W} \mathrm{CO}_{2}=\mathrm{Wtc} \times$ 3,667 dimana: WCO2 adalah banyaknya $\mathrm{CO}_{2}$ yang diserap (ton); Wtc ialah kandungan korbon di atas permukaan tanah (ton); 3,667 yang merupakan nilai berat massa atom $\mathrm{CO}_{2}(44) /$ berat massa atom $\mathrm{C}_{12}$. Data yang diperoleh kemudian ditabulasi dan di analisis secara deskriptif dengan menggunakan perangkat lunak Microsoft Office Excel. Hasil yang diperoleh kemudian di sajikan dalam bentuk tabel dan gambar.

\section{HASIL DAN PEMBAHASAN}

\section{Jenis-Jenis Tegakan Pada Pekarangan} Pemanfaatan pekarangan sudah sangat lazim dilakukan oleh masyarakat yang telah mengenal sistem pertanian modern. Kampung Mubraidiba merupakan salah satu kampung di distrik Manokwari Utara yang masyarakatnya memanfaatkan wilayah pekarangan untuk menanam tanaman jangka pendek maupun jangka panjang. Jenis-jenis tanaman tersebut antara lain: mangga (Mangifera indica), pisang (Musa sp.), kedondong (Lannea grandis), durian (Durio zibethinus), jeruk (Citrus sp.) dan rambutan (Niphelium lappaceum) yang dapat memberikan manfaat ekonomi bagi masyarakat setempat.

Jenis-jenis tanaman kehutanan, pertanian dan perkebunan ini sengaja dipilih dan ditanam secara teratur oleh masyarakat di wilayah pekarangan. Pengukuran jenisjenis tanaman di pekarangan kampung Mubraidiba dilakukan pada 2 (dua) kelas diameter, yaitu kelas diameter $5-30 \mathrm{~cm}$ dan kelas diameter $30 \mathrm{~cm}$ up.
Pengelompokan ke dalam kelas diameter ini lazim digunakan untuk pengukuran diameter pada sistem agroforestri (Hairiah dkk. 2007). Selain itu, pengelompokan tanaman juga dilakukan berdasarkan jenis tanaman kehutanan, pertanian dan perkebunan. Hasil penelitian menunjukkan bahwa jumlah jenis tanaman pertanian dan perkebunan pada kelas diameter 5 - $30 \mathrm{~cm}$ lebih banyak $(66,67 \%)$ dibanding jenis tanaman kehutanan (33,33\%). Jumlah jenis tanaman pertanian dan perkebunan sebanyak 20 jenis (spesies) yang terdiri dari: gersen (Muntingia calabura), kelapa (Cocos nucifera), cempedak (Artocarpus integra), coklat (Theobroma cacao), mangga (Mangifera indica), pisang (Musa sp.), jambu (Syzygium sp.), jeruk (Citrus sp.), rambutan (Niphelium lappaceum), nangka (Artocarpus heterophillya), alpukat (Persea americana Mill.), durian (Durio zibethinus), kedondong (Lannea grandis), langsat (Lansium domesticum), belimbing (Averhoa bilimbi), sirsak (Annona muricata), sukun (Artocarpus communis), turi (Sesbania grandiflora), pete (Leucaena leucocephala) dan pinang (Areca sp.). Sedangkan jumlah jenis tanaman kehutanan sebanyak 10 jenis (spesies) atau 33,33\% dari total tanaman di pekarangan yang terdiri dari: ketapang (Terminalia catappa), pulai (Alstonia scholaris), waru (Hibiscus sp.), matoa (Pometia pinnata), macaranga (Macaranga mappa), merbau (Intsia sp.), cemara (Casuarina sp.), putat (Baringtonia sp.), beringin (Ficus benjamina) dan gamal (Gliricidia sepium).

Selain itu hasil penelitian menunjukkan bahwa pada pohon dengan diameter 30 $\mathrm{cm}$ up, jumlah tanaman pertanian dan 
perkebunan lebih banyak (52,94\%) dibanding tanaman kehutanan $(47,06 \%)$. Jumlah jenis tanaman pertanian dan perkebunan sebanyak 9 jenis (spesies) yang terdiri dari: alpukat (Persea americana.), pisang (Musa sp.), kelapa (Cocos nucifera), durian (Durio zibethinus), jambu (Syzygium sp.), mangga (Mangifera indica), nangka (Artocarpus heterophillya), kedondong (Lannea grandis) dan sukun (Artocarpus communis). Sedangkan jumlah jenis tanaman kehutanan sebanyak 8 jenis (spesies) yang terdiri dari: beringin (Ficus benjamina), pulai (Alstonia scholaris), gamal (Gliricidia sepium), lingua (Pterocarpus indicus), waru ( Hibiscus sp.), macaranga (Macaranga mappa), ketapang (Terminalia catappa) dan matoa (Pometia pinnata).

\section{Pola Sebaran Tanaman Pekarangan}

Pada pekarangan di kampung Mubraidiba, jenis-jenis pohon yang ditanam juga sangat beragam yaitu jenisjenis tanaman pertanian dan perkebunan serta tanaman kehutanan. Jenis-jenis tanaman ini ditanam secara beraturan. Berikut ini adalah gambar salah satu pekarangan yang terdapat di kampung Mubraidiba. Pekarangan merupakan salah satu tipe agroforestri yang ada di Indonesia, pekarangan juga merupakan kebun campuran tetapi pada umumnya berada di sekitar rumah pada posisi bagian depan, belakang, samping kanan atau samping kiri tergantung ketersediaan areal serta pada umumnya disertai pagar pembatas yang jelas. Kondisi inilah yang membedakan antara kebun campuran dan pekarangan. Selain itu, fungsi antara kebun campuran dan pekarangan masih terdapat sedikit perbedaan dimana kebun campuran pada umumnya difungsikan untuk tujuan produktivitas, sedangkan pekarangan selain kadang memiliki fungsi produktivitas juga mempunyai fungsi untuk keindahan dan kenyamanan tinggal. Luas pekarangan sangat beragam, menurut Affandi (2002), luas pekarangan dapat diklasifikasikan dalam 4 kelas, yaitu: pekarangan sempit $\left(<200 \mathrm{~m}^{2}\right)$, pekarangan sedang $\left(200-500 \mathrm{~m}^{2}\right)$, pekarangan besar $\left(500-1.000 \mathrm{~m}^{2}\right)$, dan pekarangan sangat besar $\left(>1.000 \mathrm{~m}^{2}\right)$. Pekarangan di kampung Mubraidiba termasuk pada klasifikasi pekarangan sangat besar, dimana luas pekarangan di kampung ini rata-rata seluas $2.566 \mathrm{~m}^{2}$.

Selain itu, profil pekarangan di kampung Mubraidiba terdiri dari 3 lapisan (strata). Lapisan teratas (A) didominasi oleh tanaman kehutanan dan pertanian yang terdiri dari jenis ketapang (Terminalia catappa), Mangga (Mangifera indica) dan kelapa (Cocos nucifera). Lapisan menengah (B) didominasi oleh tanaman pertanian yang terdiri dari jenis pinang (Areca sp.) dan alpukat (Persea americana.). Lapisan terbawah (C) ini di dominasi oleh tanaman pertanian terdiri dari jenis pisang (Musa sp.) dan rambutan (Niphelium lappaceum).

\section{Biomassa}

Biomasa pohon merupakan total berat atau volume pohon dalam suatu area tertentu (Sutaryo 2009). Biomasa yang diukur dalam penelitian ini adalah biomasa yang terdapat pada komponen batang di atas permukaan tanah (Above Ground Biomass) yang diperoleh melalui pengukuran diameter pohon. Selain biomasa di atas permukaan tanah, terdapat juga biomasa yang terdapat di dalam tanah (Below Ground Biomassa) dan biomasa di tanaman bawah. Pendugaan biomasa pohon di atas permukaan tanah dapat dilakukan dilakukan dengan menggunakan 
persamaan alometrik yang telah tersedia. Data yang lazim digunakan dalam persamaan alometrik adalah data diameter dan tinggi pohon. Hasil perhitungan biomasa pohon dengan diameter $5-30$ $\mathrm{cm}$ dan lebih dari $30 \mathrm{~cm}$ pada pekarangan di kampung Mubraidiba distrik Manokwari Utara kabupaten Manokwari. Hasil penelitian menunjukkan bahwa total luas pekarangan di kampung Mubraidiba seluas $66.720 \mathrm{~m}^{2}$ dengan rata-rata luas per pekarangan adalah $2.566 \mathrm{~m}^{2}$ dengan luas pekarangan berkisar antara $600-20.000$ $\mathrm{m}^{2}$. Luas pekarangan yang sangat bervariasi menunjukkan tingkat penguasaan dan pemilikan lahan yang sangat bervariasi pula. Total nilai biomasa pohon dengan diameter $5-30$ $\mathrm{cm}$ pada pekarangan di kampung Mubraidiba sebesar 51,8718 ton dengan rata-rata 1,9951 ton/pekarangan. Jumlah nilai biomasa pada tanaman kehutanan sebesar 7,5797 ton $(5,40 \%)$, dengan nilai biomasa berkisar antara 0,1706 - 2,0039 ton dengan rata-rata 0,2915 ton/pekarangan, sedangkan nilai biomasa tanaman pertanian dan perkebunan sebesar 44,2921 ton $(31,55 \%)$, dengan nilai biomasa berkisar antara 0,1301 5,4914 ton dengan rata-rata 1,7035 ton/pekarangan. Sedangkan total nilai biomasa pohon dengan diameter $30 \mathrm{~cm}$ up pada pekarangan di kampung Mubraidiba sebesar 88,4977 ton dengan rata-rata 3,4038 ton/pekarangan. Jumlah nilai biomasa pada tanaman kehutanan sebesar 20,8737 ton (14,87\%), dengan nilai biomasa berkisar antara 0,7923 4,9982 ton dengan rata-rata 0,8028 ton/pekarangan, sedangkan nilai biomasa tanaman pertanian dan perkebunan sebesar 67,6240 ton $(48,18 \%)$, dengan nilai biomasa berkisar antara 0,8325 -
14,2770 ton dengan rata-rata 2,6009 ton/pekarangan.

Total keseluruhan nilai biomasa pohon yang terdapat di kampung ini sebesar 140,3694 ton dengan rata-rata 5,3988. Jika dikonversikan ke dalam satuan hektar, maka nilai biomasa pada lokasi penelitian ini rata-rata sebesar 21 ton/ha. Berdasarkan SNI (Standar Nasional Indonesia) 7645 tahun 2010 ada terdapat 21 kelas tutupan lahan, dimana 21 kelas tutupan lahan ini memiliki nilai biomasa yang berbeda-beda. Dari hasil penelitian di atas nilai biomasa pada pekarangan di kampung Mubraidiba relatif lebih rendah, yaitu hanya sebesar 21 ton/ha jika dibandingkan dengan hasil penelitian yang dilakukan oleh Badan Planologi (2012), pada lahan pertanian yang dikategorikan mirip dengan pekarangan yaitu pertanian lahan kering campur dengan nilai biomasanya sebesar 60 ton/ha. Hasil penelitian dari Boer (2001), menunjukkan bahwa nilai biomasa pada lahan yang menggunakan sistem agroforestri sebesar 188 ton/ha. Nilai biomasa yang relatif rendah ini diduga disebabkan karena jumlah tanaman yang terdapat di pekarangan lebih sedikit, kerapatan tegakan sangat rendah dan diameter pohon yang kecil. Akan tetapi, jika dibandingkan dengan penelitian dari Badan Planologi (2012), untuk pertanian lahan kering nilai biomasanya hanya sebesar 20 ton/ha. Hal ini membuktikan bahwa nilai biomasa di kampung Mubraidiba masih sedikit lebih tinggi, yaitu sebesar 21 ton/ha.

Berdasarkan hasil penelitian yang dilakukan, diketahui bahwa jumlah biomasa pada tanaman pertanian dan perkebunan lebih besar jika dibandingkan dengan tanaman kehutanan. Hal ini dipengaruhi oleh jumlah tanaman 
pertanian dan perkebunan yang lebih banyak dibandingkan dengan tanaman kehutanan. Walaupun tanaman kehutanan memiliki ukuran diameter yang besar, namun berjumlah sedikit sedangkan ukuran diameter tanaman pertanian dan perkebunan memiliki ukuran diameter yang kecil namun memiliki jumlah yang banyak, sehingga tanaman pertanian dan perkebunan memiliki jumlah biomasa yang lebih banyak.

\section{Stok Karbon}

Karbon merupakan salah satu unsur utama pembentuk bahan organik, termasuk makhluk hidup. Pendugaan stok karbon dilakukan dengan melakukan pengukuran biomasa pohon. Menurut Brown (1997), di dalam biomasa terdapat $\pm 50 \%$ karbon. Berdasarkan hal tersebut maka pendugaan stok karbon dilakukan dengan melakukan perkalian biomasa dengan angka 50\% atau 0,5. Besarnya stok karbon di berbagai tipe penggunaan dan penutupan lahan sangat berbeda-beda tergantung pada tipe vegetasi dan kerapatannya. Pada sistem agroforestri, stok karbon juga sangat bervariasi tergantung pada pola agroforestri, jenis tanaman dan kerapatan tegakan. Selain itu, faktor lain yang sangat berpengaruh adalah umur lahan agroforestri, karena umur lahan akan berkorelasi positif dengan diameter pohon dan stok karbon. Pola agroforestri pada lokasi penelitian adalah agroforestri sederhana berupa pemanfaatan pekarangan (home garden).

Hasil kajian lapangan dan studi menunjukkan bahwa total stok karbon di pekarangan kampung Mubraidiba adalah 70,1847 ton dengan rata-rata 2,6994 ton/pekarangan atau sebesar 10,5 ton/ha, yang terdiri dari stok karbon pada pohon dengan diameter $5-30 \mathrm{~cm}$ sebanyak
25,9361 ton dan pada pohon dengan diameter $30 \mathrm{~cm}$ up sebanyak 44,2486 ton. Stok karbon pada tanaman kehutanan dengan diameter $5-30 \mathrm{~cm}$ sebesar 3,7898 ton $(5,40 \%)$, dengan nilai stok karbon berkisar antara 0,0853 - 1,0019 ton dengan rata-rata 0,1458 ton/pekarangan, sedangkan stok karbon tanaman pertanian dan perkebunan sebesar 22,1463 ton $(31,55 \%)$ dengan nilai stok karbon berkisar antara 0,0651 2,7457 ton dengan rata-rata 0,8518 ton/pekarangan. Jumlah stok karbon pada tanaman kehutanan dengan diameter 30 $\mathrm{cm}$ up sebesar 10,4367 ton $(14,87 \%)$ dengan stok karbon berkisar antara $0,3961-2,4991$ ton dengan rata-rata 0,4014 ton/pekarangan, sedangkan stok karbon tanaman pertanian dan perkebunan sebesar 33,8119 ton (48,18\%), dengan stok karbon berkisar antara 0,4163 ton $-7,1385$ ton dengan rata-rata 1,3005 ton/pekarangan.

Dari hasil penelitian diatas, besarnya stok karbon pada pekarangan di kampung Mubraidiba relatif lebih rendah, yaitu hanya sebesar 10,5 ton/ha jika dibadingkan dengan hasil penelitian yang dilakukan oleh Badan Planologi (2012), pada lahan pertanian yang dikategorikan mirip dengan pekarangan yaitu pertanian lahan kering campur dengan stok karbon sebesar 30 ton/ha. Hasil penelitian dari Boer (2001), menunjukkan bahwa besarnya stok karbon pada lahan yang menggunakan sistem agroforestri sebesar 94 ton/ha. Stok karbon yang relatif rendah ini diduga disebabkan karena jumlah tanaman yang terdapat di pekarangan lebih sedikit, kerapatan tegakan sangat rendah dan diameter pohon yang kecil. Akan tetapi, jika dibandingkan dengan penelitian dari Badan Planologi (2012), untuk pertanian lahan kering dengan 
jumlah stok karbon hanya sebesar 10 ton/ha. Hal ini membuktikan bahwa jumlah stok karbon di kampung Mubraidiba masih sedikit lebih tinggi, yaitu sebesar 10,5 ton/ha.

Berdasarkan hasil penelitian yang dilakukan, diketahui bahwa jumlah stok karbon pada tanaman pertanian dan perkebunan lebih besar jika dibandingkan dengan tanaman kehutanan. Hal ini dipengaruhi oleh jumlah tanaman pertanian dan perkebunan yang lebih banyak dibandingkan dengan tanaman kehutanan. Walaupun tanaman kehutanan memiliki ukuran diameter yang besar, namun berjumlah sedikit sedangkan ukuran diameter tanaman pertanian dan perkebunan memiliki ukuran diameter yang kecil namun memiliki jumlah yang banyak, sehingga tanaman pertanian dan perkebunan memiliki jumlah stok karbon yang lebih banyak.

\section{Kontribusi Pekarangan Terhadap Penurunan Emisi $\mathrm{CO}_{2}$}

Emisi $\mathrm{CO}_{2}$ merupakan berat jenis unsur karbondioksida di udara yang mengambarkan banyaknya $\mathrm{CO}_{2}$ yang diserap oleh tanaman. Untuk mengetahui jumlah emisi yang diserap dapat dihitung dengan menggunakan persamaan alometrik dari Brown, dimana hasil dari nilai stok karbon dikalikan dengan angka 3,667. Kemampuan suatu tutupan lahan di dalam pengurangan emisi gas $\mathrm{CO}_{2}$ dapat diukur dengan jumlah $\mathrm{CO}_{2}$ yang terserap di dalam suatu tutupan lahan. Dalam skema REDD+, aksi pengurangan emisi (mitigasi) dikelompokkan dalam 2 (dua) kelompok besar, yaitu stabilisasi serapan karbon dan peningkatan serapan karbon (Ekawati et al. 2012). Pemanfaatan pekarangan sebagai salah satu bentuk agroforestri sederhana merupakan salah satu aksi mitigasi yang tergolong dalam kelompok aksi mitigasi peningkatan stok karbon (enhancing carbon stock).

Hasil penelitian menunjukkan bahwa total nilai $\mathrm{CO}_{2}$ terserap sebesar 257,3671 ton $\mathrm{CO}_{2}$ dengan rata-rata 9,8987 ton $\mathrm{CO}_{2}$ /pekarangan atau 257,3671 ton $\mathrm{CO}_{2}$ dengan rata-rata 9,8987 ton $\mathrm{CO}_{2} /$ pekarangan atau sebesar 38,5764 ton $\mathrm{CO}_{2} /$ ha. Karbondioksida terserap pada pohon dengan diameter $5-30 \mathrm{~cm}$ pada pekarangan di kampung Mubraidiba sebesar 95,1068 ton $\mathrm{CO}_{2}$ dengan rata-rata 3,6580 ton/pekarangan. Jumlah $\mathrm{CO}_{2}$ terserap pada tanaman kehutanan sebesar 13,8974 ton $\mathrm{CO}_{2}(5,40 \%)$, dengan nilai $\mathrm{CO}_{2}$ terserap berkisar antara 0,3129 3,6741 ton $\mathrm{CO}_{2}$ dengan rata-rata 0,5343 ton $\mathrm{CO}_{2}$ /pekarangan, sedangkan nilai $\mathrm{CO}_{2}$ terserap tanaman pertanian dan perkebunan sebesar 81,2094 ton $\mathrm{CO}_{2}$ $(31,55 \%)$, dengan nilai $\mathrm{CO}_{2}$ terserap berkisar antara 0,2386-10,0684 ton $\mathrm{CO}_{2}$ dengan rata-rata 3,1234 ton $\mathrm{CO}_{2} /$ pekarangan. Total nilai $\mathrm{CO}_{2}$ terserap pohon dengan diameter $30 \mathrm{~cm}$ up pada pekarangan di kampung Mubraidiba sebesar 162,2603 ton $\mathrm{CO}_{2}$ dengan ratarata 6,2408 ton $\mathrm{CO}_{2}$ /pekarangan. Jumlah $\mathrm{CO}_{2}$ terserap pada tanaman kehutanan sebesar 38,2717 ton $\mathrm{CO}_{2} \quad(14,87 \%)$, dengan nilai $\mathrm{CO}_{2}$ terserap berkisar antara 1,4527 - 9,1641 ton $\mathrm{CO}_{2}$ dengan rata-rata 1,4720 ton $\mathrm{CO}_{2} /$ pekarangan. Sedangkan nilai $\mathrm{CO}_{2}$ terserap tanaman pertanian dan perkebunan sebesar 123,9886 ton $\mathrm{CO}_{2}$ $(48,18 \%)$, dengan nilai $\mathrm{CO}_{2}$ terserap berkisar antara $1,5264-26,1768$ ton $\mathrm{CO}_{2}$ dengan rata-rata 4,7688 ton $\mathrm{CO}_{2} /$ pekarangan.

Berdasarkan hasil penelitian yang dilakukan, diketahui bahwa tanaman kehutanan lebih sedikit dalam menyerap $\mathrm{CO}_{2}$ bila dibandingkan dengan tanaman 
pertanian dan perkebunan. Hal ini dipengaruhi oleh jumlah tanaman pertanian dan perkebunan yang lebih banyak dibandingkan dengan tanaman kehutanan. Walaupun tanaman kehutanan memiliki ukuran diameter yang besar, namun berjumlah sedikit sedangkan ukuran diameter tanaman pertanian dan perkebunan memiliki ukuran diameter yang kecil namun memiliki jumlah yang banyak, sehingga tanaman pertanian dan perkebunan memiliki jumlah $\mathrm{CO}_{2}$ terserap yang lebih banyak.

\section{Rekapitulasi Variabel Pengamatan}

Data hasil penelitian secara umum dikelompokkan ke dalam kelompok tanaman kehutanan serta tanaman pertanian dan perkebunan. Selain itu pengelompokkan juga dilakukan berdasarkan kelas diameter yaitu kelas diameter $5-30 \mathrm{~cm}$ dan $30 \mathrm{~cm}$ up. Data hasil rekapitulasi hasil penelitian dapat dilihat pada Tabel 1.

Tabel 1. Rekapitulasi data biomasa, stok karbon, $\mathrm{CO}_{2}$ terserap dan nilai ekomoni $\mathrm{CO}_{2}$ terserap berdasarkan kelas diameter dan kelompok jenis.

\begin{tabular}{|c|c|c|c|c|c|c|c|}
\hline \multirow[t]{2}{*}{ No. } & \multirow[t]{2}{*}{ Jenis tanaman } & \multicolumn{2}{|c|}{ Biomasa } & \multicolumn{2}{|c|}{ Stok karbon } & \multicolumn{2}{|c|}{$\mathrm{CO}_{2}$} \\
\hline & & Ton & $\%$ & Ton & $\%$ & Ton & $\%$ \\
\hline \multicolumn{8}{|c|}{ Kehutanan } \\
\hline \multirow[t]{4}{*}{1.} & Diameter $5-30 \mathrm{~cm}$ & 7,5798 & 5,40 & 3,7898 & 5,40 & 13,8974 & 5,40 \\
\hline & Diameter $30 \mathrm{~cm}$ up & 20,8737 & 14,87 & 10,4367 & 14,87 & 38,2717 & 14,87 \\
\hline & Sub total 1 & 28,4535 & 20,27 & 14,2265 & 20,27 & 52,1691 & 20,27 \\
\hline & \multicolumn{7}{|c|}{ Pertanian dan Perkebunan } \\
\hline \multirow[t]{4}{*}{2.} & Diameter $5-30 \mathrm{~cm}$ & 44,2919 & 31,55 & 22,1463 & 31,55 & 81,2094 & 31,55 \\
\hline & Diameter $30 \mathrm{~cm}$ up & 67,6240 & 48,18 & 33,8119 & 48,18 & 123,9886 & 48,18 \\
\hline & Sub Total 2 & 111,9159 & 79,73 & 55,9582 & 79,73 & 205,198 & 79,73 \\
\hline & Total $1+2$ & 140,3694 & 100,00 & 70,1847 & 100,00 & 257,3671 & 100,00 \\
\hline
\end{tabular}

Berdasarkan pengelompokkan pada Tabel 1, jumlah biomasa, stok karbon dan $\mathrm{CO}_{2}$ terserap serta nilai ekonomi $\mathrm{CO}_{2}$ terserap tertinggi dijumpai pada kelompok tanaman pertanian dan perkebunan, yaitu sebesar 79,33\% dan tanaman kehutanan

\section{DAFTAR PUSTAKA}

Affandi O. 2002. Home Garden: Sebagai salah satu sistem agroforestry lokal. Fakultas Kehutanan Program Ilmu Kehutanan Universitas Sumatera Utara. Sumatera Utara. sebesar 20,27\%. Sedangkan berdasarkan kelas diameter, jumlah biomasa, stok karbon dan $\mathrm{CO}_{2}$ terserap serta nilai ekonomi $\mathrm{CO}_{2}$ terserap pada kelas diameter $30 \mathrm{~cm}$ up sebesar $63,05 \%$ dan kelas diameter $5-30 \mathrm{~cm}$ sebesar $36,95 \%$

Arifin, J. 2001. Estimasi cadangan karbon pada berbagai sistem penggunaan lahan di Kecamatan Ngantang, Malang, Jurusan Tanah, Fakultas Pertanian, Universitas Brawijaya, Malang, 61pp. Badan Planologi. 2012. Stok Karbon pada Berbagai Tutupan Lahan di Indonesia. Jakarta. 
Badan Planologi. 2012. Stok Karbon pada Berbagai Tutupan Lahan di Indonesia. Jakarta.

Balai Pemantapan Kawasan Hutan (BPKH) Wilayah XVII. 2012. Peran BPKH Wilayah XVII dalam Menunjang REDD+ di Papua Barat. Manokwari.

Boer R. 2001. Economic Assessment of Technology Option for Enchanching and Maintaining Carbonk Sink Capacity in Indonesia Accepted for Publication at Mitigation Adaptation Strategisfor Global Change 6:257290.

Brown.1997. Estimating Biomass and Biomass Change of Tropical Forest : a Primerr. Rome, Italy : FAO Foretsry Paper 134.

Ekawati S, Ginoga, K.L, Wibowo A, Subarudi, Salaka F, Rochmayanto Y, Muttaqin M.Z, Savitri S. 2012. Identifikasi Kegiatan-Kegiatan yang Mengurangi Emisi Karbon Melalui Peningkatan Serapan Karbon dan Stabilitasi Simpanan Karbon Hutan di Indonesia. Pusat Penelitian dan Pengembangan Perubahan Iklim dan Kebijakan, Badan Penelitian dan Pengembangan Kehutanan, Bogor, Indonesia.
Hairiah K, Ekadinata A, Sari RR, Rahayu S. 2011. Pengukuran Cadangan Karbon: dari tingkat lahan ke bentang lahan. Petunjuk Praktis. Edisi kedua. Bogor, World agroforestry centre, ICRAF SEA Regional Office, University Of Brawijaya (UB), Malang, Indonesia xx p.

Hairiah K, Rahayu S. 2007. Pengukuran "karbon tersimpan" di berbagai macam penggunaan lahan. Bogor. World Agroforestry Centre-ICRAF, SEA Regional Office, University of Brawijaya, Unibraw, Indonesia. $77 \mathrm{p}$.

Standar Nasional Indonesia. 2010. Klasifikasi penutupan lahan. SNI 7645:2010. Badan Standar Nasional

Sutaryo D. 2009. Perhitungan Biomassa. Wetland International Programme. Bogor, Jawa Barat.

Wibowo A, Irawanti S, Muttaqin Z, Subarudi, Nurfatriani F, Sakuntaladewi N, Widyaningtyas N, Siran AS. 2012. Prosiding Workshop Kerjasama International. Pusat Penelitian dan Pengembangan Perubahan Iklim dan Kebijakan, Badan Penelitian. 